\title{
THE EFFECTIVE STIMULUS FOR INCREASED PULMONARY VENTILATION DURING MUSCULAR EXERTION
}

\author{
By JULIO M. BARMAN,1 MANOEL F. MOREIRA,2 AND FRANK CONSOLAZIO \\ (From the Fatigue Laboratory, Harvard University, Morgan Hall, Soldiers' Field, Boston)
}

(Received for publication July 21, 1942)

The control of the pulmonary ventilation is a central problem in the physiology of muscular exercise. The hypothesis that the respiratory center is stimulated by chemical changes in the arterial blood has been defended by Gesell (1), Haldane (2), and Henderson (3). In addition to this type of stimulation, Krogh and Lindhard (4) have discussed the anticipatory hyperventilation preceding and immediately following the onset of exercise. This they attribute to cerebral cortical stimulation. Recently, Harrison and his associates $(5,6)$ have maintained that the stimulus for the increase in pulmonary ventilation in men and dogs during very moderate exercise, either active or passive, is not chemical, but is reflex. Comroe and Schmidt (7) confirmed these findings in anesthetized dogs, using either electrical stimulation of the lumbar anterior spiral roots, or else passive movements of the limbs. In view of the importance of this problem, we have repeated Harrison's experiments, which use light exercise, and have extended them to include a more strenuous grade of exercise, in which the changes in ventilation are larger and more consistent from experiment to experiment and from subject to subject.

\section{EXPERIMENTAL METHODS}

Two different types of experiments have been made: (1) In the first type, using the arm muscles of recumbent subjects, ventilation was measured: (a) at rest; (b) at rest, with the circulation of both arms cut off at the level of the distal insertion of the deltoids; (c) during exercise of the flexors of the hand, with the circulation normal; $(d)$ during the same exercise continued to exhaustion, with the circulation cut off ; $(e)$ immediately after restoration of the circulation. After each period of exercise the subject was allowed to rest until he regained his basal condition. The exercise consisted in squeezing inflated rubber bulbs with each hand 60 times per minute at a rate of work of 12 kilogrammeters per minute for $1 \frac{1}{2}$ minutes, or squeezing a bulb with one hand and moving an ergograph with the other. Sphyg-

\footnotetext{
1 Rockefeller Fellow.
}

2 Pan-American Fellow. momanometer cuffs inflated to $200 \mathrm{~mm}$. $\mathrm{Hg}$ were used to cut off the circulation.

(2) In the second type, the leg muscles were used. The subject walked on a motor-driven treadmill, at a grade of 8.6 per cent, and a speed of 2.4 or 3.5 m.p.h., until a steady state was reached. While still walking, the circulation of both legs was cut off by inflating, to a pressure of $200 \mathrm{~mm}$. $\mathrm{Hg}$, sphygmomanometer cuffs placed around the legs at the level of the distal insertion of the gluteal muscles. After a given time, usually $1 \frac{1}{2}$ minutes, the pressure was relieved and the subject continued to walk, until the previous steady state was reached, usually within 10 minutes. Ventilation was measured during this steady state, then during the ischemia, and finally after release of the pressure.

\section{RESULTS}

Table I shows the results of the first type of experiments, in which recumbent subjects exercise

TABLE I

Pulmonary ventilation of recumbent normal subjects under conditions stipulated

\begin{tabular}{|c|c|c|c|c|c|c|}
\hline \multirow[b]{2}{*}{$\begin{array}{l}\text { Sub- } \\
\text { ject }\end{array}$} & \multirow[b]{2}{*}{$\begin{array}{c}\text { Experi- } \\
\text { ment } \\
\text { number }\end{array}$} & \multicolumn{5}{|c|}{ Condition of subject } \\
\hline & & $\begin{array}{c}\text { Rest- } \\
\text { ing }\end{array}$ & $\begin{array}{c}\text { Resting } \\
\text { and } \\
\text { ischemic }\end{array}$ & $\begin{array}{c}\text { Exer- } \\
\text { cising, } \\
\text { no } \\
\text { ischemia }\end{array}$ & $\begin{array}{c}\text { Exer- } \\
\text { cising, } \\
\text { arms } \\
\text { ischemic }\end{array}$ & $\begin{array}{l}\text { Resting, } \\
\text { first } \\
\text { minute } \\
\text { after } \\
\text { ischemia }\end{array}$ \\
\hline & & \multicolumn{5}{|c|}{ liters per minute, dry at S.T.P. } \\
\hline Bar & $\begin{array}{r}1 \\
2 \\
3 \\
4 \\
5 \\
6 \\
7 \\
8 \\
9 \\
10\end{array}$ & $\begin{array}{l}6.90 \\
7.50 \\
7.20 \\
6.40 \\
6.80 \\
6.80 \\
6.70 \\
6.70 \\
6.72 \\
7.00\end{array}$ & $\begin{array}{l}7.00 \\
8.20 \\
8.00 \\
7.60 \\
7.80 \\
7.50 \\
6.90 \\
6.70 \\
7.20 \\
7.80\end{array}$ & $\begin{array}{l}8.10 \\
8.90 \\
8.50 \\
7.60 \\
8.10 \\
9.00 \\
6.80 \\
7.30 \\
7.20 \\
7.20\end{array}$ & \begin{tabular}{|l}
7.30 \\
8.90 \\
8.50 \\
7.00 \\
7.80 \\
8.10 \\
7.10 \\
7.30 \\
7.20 \\
7.00
\end{tabular} & $\begin{array}{l}12.4 \\
13.0 \\
12.2 \\
14.5 \\
13.5 \\
12.5 \\
16.0\end{array}$ \\
\hline Mor & $\begin{array}{r}1 \\
2 \\
3 \\
4 \\
5 \\
6 \\
7 \\
8 \\
9 \\
10 \\
11\end{array}$ & $\begin{array}{l}6.70 \\
7.74 \\
7.80 \\
6.80 \\
6.80 \\
7.95 \\
6.75 \\
7.80 \\
8.10 \\
7.80 \\
6.90\end{array}$ & $\begin{array}{l}9.00 \\
7.74 \\
8.20 \\
7.60 \\
6.90 \\
8.20 \\
6.80 \\
7.85 \\
8.00 \\
8.00 \\
8.10\end{array}$ & $\begin{array}{l}8.90 \\
8.40 \\
7.90 \\
7.70 \\
8.60 \\
8.45 \\
7.43 \\
7.85 \\
9.90 \\
9.50 \\
9.10\end{array}$ & $\begin{array}{r}8.90 \\
7.90 \\
9.10 \\
7.80 \\
9.10 \\
8.00 \\
6.75 \\
7.20 \\
9.00 \\
10.00 \\
8.00\end{array}$ & $\begin{array}{l}12.8 \\
15.0\end{array}$ \\
\hline Hol & $\begin{array}{l}1 \\
2\end{array}$ & $\begin{array}{l}6.80 \\
6.50\end{array}$ & $\begin{array}{l}8.10 \\
7.10\end{array}$ & $\begin{array}{l}8.50 \\
8.80\end{array}$ & $\begin{array}{l}8.20 \\
8.20\end{array}$ & $\begin{array}{l}14.0 \\
12.0\end{array}$ \\
\hline
\end{tabular}


the flexors of the hands. It should be compared with Table III of Harrison (5), and differs from his results in the following ways: (1) mere ischemia nearly always produced a slight increase in ventilation at rest; (2) exercising the flexors of the hands, without ischemia of the arms, always increased the ventilation, but to a far smaller extent than shown by Harrison; (3) exercising the flexors of the hands with the arms ischemic usually produced a decrease in ventilation below the value for the same exercise with circulation intact; (4) release of the ischemia produced at once a marked increase in ventilation (this increase was not remarked upon by Harrison (5), nor is it shown in his tables); (5) the changes were so small that their significance is hard to evaluate, except in the case of the marked hyperventilation after ischemia.

Our results, therefore, lead to the following conclusions: (1) that ischemia during exercise of this very mild sort usually results in diminution in ventilation in comparison with exercise with normal circulation; and, ( 2 ) that after ischemia is released, a large increase in ventilation occurs. These findings can only be explained by chemical stimulation of the respiratory centers and not by reflex stimulation. In these experiments, the external work was about 12 kilogrammeters per minute, and the extra oxygen consumption of the subjects was only about $30 \mathrm{cc}$. per minute, a figure which agrees well with the calculated work done.

In view of the small changes in ventilation produced by this type of exercise, and the difficulty in standardizing the work, we decided to employ a well-standardized exercise, easy to control, and producing relatively large changes in ventilation. In this way, we hoped to get consistent, clear cut results.

Table II shows typical results of experiments with subjects walking on the treadmill, first in a steady state, then with ischemia of both legs, and finally after the release of the ischemia ( $c f$. experiments of type 2 in Experimental Methods). The data for ventilation in the first one or two experiments on each subject show some variability. However, after the subjects became used to the discomfort of the experimental condition, ischemia always produced a marked decrease in pulmonary ventilation, to be followed after release of the ischemia by a marked rise above the level of the steady state and a return, within 10 minutes, to the level of the steady state. It will be seen that ischemia in every experiment produced a marked decrease in the oxygen consumption, and release of the pressure was always followed by a marked increase above the level of the steady state.

The data in Table II lead to the following conclusions and interpretations:

(1) Subjects must be exposed to this type of experiment several times before the results become reliable.

(2) Even though the nervous connections remain intact, total ischemia of the legs during walking causes a decrease in the pulmonary ventilation.

TABLE II

Pulmonary ventilation and oxygen consumption in normal men walking at a speed of 3.5 m.p.h. and a grade of 8.6 per cent

\begin{tabular}{|c|c|c|c|c|c|c|c|c|c|}
\hline \multirow{2}{*}{ Subject } & \multirow{2}{*}{ Condition } & \multicolumn{4}{|c|}{ Pulmonary ventilation } & \multicolumn{4}{|c|}{ Oxygen consumption } \\
\hline & & 1 st expt. & 2nd expt. & 3rd expt. & 4th expt. & 1st expt. & 2nd expt. & 3rd expt. & 4th expt. \\
\hline & & \multicolumn{4}{|c|}{ liters per minute } & \multicolumn{4}{|c|}{ liters per minute } \\
\hline Bar & $\begin{array}{l}\text { Steady state, no ischemia } \\
\text { During ischemia } \\
\text { First minute after ischemia } \\
\text { Ten minutes after ischemia }\end{array}$ & $\begin{array}{l}46.3 \\
43.4 \\
64.0 \\
48.0\end{array}$ & $\begin{array}{l}43.0 \\
43.9 \\
54.5 \\
44.5\end{array}$ & $\begin{array}{l}43.7 \\
36.9 \\
65.4 \\
44.2\end{array}$ & $\begin{array}{l}43.7 \\
38.2 \\
55.4 \\
44.0\end{array}$ & $\begin{array}{l}1.485 \\
1.115 \\
1.860 \\
1.500\end{array}$ & $\begin{array}{l}1.570 \\
1.200 \\
2.000 \\
1.590\end{array}$ & $\begin{array}{l}1.500 \\
1.142 \\
2.000 \\
1.580\end{array}$ & $\begin{array}{l}1.525 \\
1.146 \\
1.950 \\
1.560\end{array}$ \\
\hline Mor & $\begin{array}{l}\text { Steady state, no ischemia } \\
\text { During ischemia } \\
\text { First minute after ischemia } \\
\text { Ten minutes after ischemia }\end{array}$ & $\begin{array}{l}29.6 \\
28.0 \\
43.2 \\
32.1\end{array}$ & $\begin{array}{l}34.0 \\
39.2 \\
54.3 \\
33.6\end{array}$ & $\begin{array}{l}36.7 \\
29.9 \\
46.3 \\
38.8\end{array}$ & $\begin{array}{l}36.0 \\
33.5 \\
50.1 \\
35.2\end{array}$ & $\begin{array}{l}1.320 \\
1.000 \\
2.210 \\
1.320\end{array}$ & $\begin{array}{l}1.400 \\
1.090 \\
2.000 \\
1.420\end{array}$ & $\begin{array}{l}1.360 \\
1.100 \\
2.100 \\
1.400\end{array}$ & $\begin{array}{l}1.390 \\
1.080 \\
2.050 \\
1.410\end{array}$ \\
\hline Con & $\begin{array}{l}\text { Steady state, no ischemia } \\
\text { During ischemia } \\
\text { First minute after ischemia } \\
\text { Ten minutes after ischemia }\end{array}$ & $\begin{array}{l}48.6 \\
45.4 \\
70.5 \\
48.2\end{array}$ & $\begin{array}{l}48.0 \\
43.0 \\
70.0 \\
50.0\end{array}$ & $\begin{array}{l}45.0 \\
43.2 \\
68.8 \\
47.0\end{array}$ & & $\begin{array}{l}2.490 \\
1.560 \\
3.425 \\
2.480\end{array}$ & $\begin{array}{l}2.400 \\
1.610 \\
3.510 \\
2.390\end{array}$ & $\begin{array}{l}2.480 \\
1.680 \\
3.240 \\
2.490\end{array}$ & \\
\hline
\end{tabular}


The stimulus to ventilation during walking must therefore be chiefly of chemical, not reflex, origin.

(3) After release of the ischemia, even though the nervous connections remain unaffected, there is a marked increase of ventilation which must be caused by chemical stimuli. This conclusion has been verified by estimation of the blood lactate, and the results will be discussed elsewhere (8).

\section{DISCUSSION}

Our results are in agreement with the hypotheses of Gesell (1), Haldane (2), and Henderson (3) that the respiratory centers are stimulated chemically, whether it be by the $\mathrm{pH}$ of the arterial blood, or by other circulating factors affecting the intrinsic metabolism of the centers, and with the findings of Jarisch and Gaisböck (9) with resting men, in whom ischemia was accomplished by a significant decrease in oxygen consumption, and in whom, relief of the ischemia produced at once a hyperventilation with increased oxygen consumption.

The discrepancies between our results, using very light exercise, and Harrison's (5) are difficult to explain. It is possible that the anticipatory hyperventilation shown by Krogh and Lindhard (4) plays some part in Harrison's results. We have found that even subjects well accustomed to the procedures involved in studying muscular exercise in the laboratory, showed variable results during the first few experiments, and only after several days began to give consistent results. In our experience, no normal subject accustomed to the experimental procedure has had a ventilation as high as those reported by Harrison (5), under experimental conditions similar to his. The chief difficulties with using light exercise are that the work is hard to standardize, and that the changes in ventilation are small. When a heavier grade of work is used, these difficulties disappear, since voluntary and subconscious factors which can easily influence pulmonary ventilation in man at rest or doing very light exercise, become less and less effective with increasing rates of muscular work. In fact, during exercise that exhausts within a few minutes, voluntary alteration of the pulmonary minute-volume is virtually impossible.

All of the results reported in the present paper are consistent with the hypothesis that increase in ventilation in exercise is caused predominantly by chemical stimulation, and not by reflex stimulation from the leg.

\section{SUM MARY}

1. The increase in pulmonary ventilation has been studied in normal men exercising the limbs, first with normal circulation, and then with the circulation cut off by pressure from inflated cuffs.

2. Very light exercise (at a rate of 12 kilogrammeters per minute) of the flexors of the hand during total ischemia of the arms usually resulted in a smaller ventilation than when the arms had normal circulation. Release of the ischemia was followed at once by a marked hyperventilation.

3. In subjects walking uphill on a treadmill (at a rate of 700 kilogrammeters per minute for a 90 kilo subject), total ischemia of both legs resulted in a marked diminution of pulmonary ventilation, even though the nervous pathways were intact, and release of the ischemia was followed at once by a marked hyperventilation, much higher than the value prior to ischemia.

4. These results are interpreted to mean that the chemical stimulus for increased ventilation in exercise of these types is far more important than the reflex.

5. The discrepancies between our results and Harrison's (5) are perhaps due to the fact that consistent results are found only after the subjects have become well accustomed to the experimental procedures by several repetitions of the experiments, and when exercise of sufficient severity is used so that the changes in ventilation and oxygen consumption are relatively large in magnitude.

We wish to thank Drs. Robert Johnson, Robert Darling, and William Forbes, and the other members of the laboratory for their help in this work.

\section{BIBLIOGRAPHY}

1. Gesell, R., The chemical regulation of respiration. Physiol. Rev., 1925, 5, 551.

2. Haldane, J. S., and Priestley, J. G., Respiration. Yale University Press, New Haven, 1935, 2nd edition.

3. Henderson, L. J., Blood. A Study in General Physiology. Yale University Press, New Haven, 1928.

4. Krogh, A., and Lindhard, J., The regulation of respiration and circulation during the initial stages of muscular work. J. Physiol., 1913, 47, 112. 
5. Harrison, T. R., Harrison, W. G., Calhoun, J. A., and Marsh, J. P., Congestive heart failure. The mechanism of dyspnea on exertion. Arch. Int. Med., 1932, 50, 690.

6. Harrison, T. R., Calhoun, J. A., Cullen, G. E., Wilkins, W. E., and Pilcher, C., Studies in congestive heart failure. XV. Reflex versus chemical factors in production of rapid breathing. J. Clin. Invest., 1932, 11, 133.
7. Comroe, J. H., and Schmidt, C. F., Proc. of the Federation of American Societies for Experimental Biology, 1942.

8. Barman, J. M., Moreira, M. F., and Consolazio, F., Metabolic effects of local ischemia during muscular . exercise. Am. J. Physiol. (In press.)

9. Jarisch, A., and Gaisböck, F., Uber das Verhalten des Kreislaufes bei der postanämischen Hyperämie. Arch. f. exper. Path. u. Pharmakol., 1929, 139, 159. 